\title{
PROBLEMATIKA PENDIRIAN RUMAH IBADAH AGAMA BUDDHA DI KOTA TANGERANG
}

\author{
Warsito \\ STABN Sriwijaya Tangerang Banten \\ warsitosuranata79@gmail.com
}

\begin{abstract}
ABSTRAK
Pelaksanaan ibadah umat beragama adalah hal mendasar bagi setiap umat beragama yang dijamin oleh negara. Dasar Hukum yang digunakan adalah adalah Surat Keputusan Bersama Menteri Agama dan Menteri Dalam Negeri No. 01/BerMDN-MAG/1969 Tanggal 13 September 1969. Kasus pengerusakan tempat ibadah oleh kelompok-kelompok tertentu pada tahun belakangan ini sempat menyulut ketegangan antara umat beragama. Bentuk diskriminatif terhadap agama dalam berbagai hal seharusnya tidak boleh terjadi dalam sebuah negara yang berasaskan Pancasila. Pemerintah mengeluarkan Peraturan Bersama 2 Menteri sebagai acuan mendirikan rumah ibadah yaitu Peraturan Bersama Menteri Agama dan Menteri Dalam Negeri (PBMA dan MDN) Nomor 8 Tahun 2006 dan Nomor 9 Tahun 2006, selanjutnya disebut SKB 2 Menteri, yang membahas tentang pendirian rumah ibadah dan pedoman penyiaran agama. Pemerintah seharusnya mengusahakan untuk membuat aturan-aturan penjelas yang lebih detail, 2 hal yang saling berkaitan, yaitu pembinaan kerukunan umat beragama melalui pembentukan Forum Kerukunan Umat Beragama (FKUB) dan prosedur pendirian rumah ibadah.

Penelitian ini bertitik tolak pada kerangka pemikiran keagamaan yang membahas mengenai Problematika Pendirian Rumah Ibadah Agama Buddha kemudian di analisis makna yang terkandung di dalamnya. Di dalam penelitian ini, metode yang digunakan adalah metode penelitian kualitatif dengan model Miles and Huberman. Berdasarkan dari hasil penelitian dan pembahasan maka dapat disimpulkan bahwa Problematika yang terjadi dalam proses pendirian rumah ibadah adalah problem internal dan eksternal. Problem Internal seperti perbedaan pendapat dan kepentingan. Problem tersebut dapat diatasi dengan cara musyawarah antar pengurus vihara dan umat Buddha. Problem eksternal yang terjadi adalah adanya protes dari masyarakat dengan tidak menyetujui adanya tempat ibadah agama Buddha. Melalui komunikasi dengan tokoh masyarakat setempat maka masalah eksternal ini dapat diatasi dengan melakukan forum dialog yang lebih membuka kesempatan mendengar penjelasan masing-masing pihak yang berkonflik pada akhirnya konflik dapat diidentifikasi, dan dapat diatasi dengan baik.
\end{abstract}

Kata Kunci: Problematika, Pendirian Rumah Ibadah Agama Buddha, Kota Tangerang 


\begin{abstract}
Implementation of religious worship is fundamental for every religious people guaranteed by the state. The legal basis used is the Joint Decree of the Minister of Religious Affairs and Minister of Home Affairs. 01/Ber-MDN-MAG/1969 September 13, 1969. The case of vandalism of places of worship by certain groups in recent years sparked tension between religious people. Discriminatory forms of religion in many respects should not occur in a country based on Pancasila. The Government issued a Joint Regulation of 2 Ministers as a reference for establishing houses of worship, namely Joint Regulation of the Minister of Religious Affairs and Minister of Home Affairs (PBMA and MDN) Number 8 of 2006 and Number 9 of 2006, hereinafter referred to as SKB 2 Minister, which discusses the establishment of houses of worship and broadcasting guidelines religion. The government should seek to make the rules of explanation in more detail, 2 interrelated matters, namely the fostering of religious harmony through the establishment of Forum Kerukunan Umat Beragama (FKUB) and the procedures for the construction of houses of worship.

This research is based on the framework of religious thought which discusses the Problematic of Establishment of Buddhist House of Worship then in the analysis of the meaning contained in it. In this research, the method used is qualitative research method with Miles and Huberman model. Based on the results of research and discussion it can be concluded that the problems that occur in the process of building houses of worship are internal and external problems. Internal issues such as differences of opinion and interests. The problem can be solved by deliberation between the Buddhist monastery and Buddhist monks. External problems that occur is the protest of the community by not agreeing to a place of Buddhist worship. Through communication with local community leaders, these external problems can be overcome by conducting a dialogue forum which is more open to hear the explanations of each conflicting party in the end the conflict can be identified, and can be addressed properly.
\end{abstract}

Keywords: Problematic, Establishment of Buddhist House of Worship, Tangerang City 


\section{A. PENDAHULUAN}

Pertumbuhan penduduk di Kota Tangerang mengalami banyak peningkatan. Pengaruh migran yang masuk lebih disebabkan karena mempunyai daya tarik Kota di pinggiran Ibukota negara. Potensi Kota Tangerang berasal dari sektor industri, perdagangan dan jasa sehingga menjadi peluang tersedianya lapangan kerja. Sebagai daerah yang berbatasan dengan Jakarta, Tangerang harus menampung pula penduduk yang aktifitas ekonomi sehari-hari di wilayah Jakarta Dalam bidang agama Kota Tangerang dikenal sebagai kota yang religius. Untuk itu praktik agama dijalankan dengan baik dalam kesehariannya. Proses menjalankan ajaran agama dengan pergi ke tempat ibadah. Pelaksanaan ibadah umat beragama adalah hal mendasar bagi setiap umat beragama yang jamin oleh negara. Dasar hukum yang dipergunakan adalah melalui Surat Keputusan Bersama Menteri Agama dan Menteri Dalam Negeri Nomor 01/Ber-MDN-MAG/1969 Tanggal 13 September 1969. Kasus Intoleransi pernah terjadi dalam kehidupan umat beragama Kota Tangerang. Intoleransi kehidupan beragama yang kurang kondusif salah satunya karena disebabkan oleh peraturan SKB Nomor 01/Ber-MDN-MAG/1969, belum mengatur secara rinci prosedur pendirian tempat ibadah.

Bentuk diskriminatif terhadap agama dalam berbagai ketentuan perundangan seharusnya tidak boleh terjadi dalam sebuah negara yang berasaskan Pancasila. Dalam Peraturan Bersama Nomor 01/Ber-MDNMAG/1969 Tanggal 13 September 1969 yang selama ini justru menjadi penghalang bagi pembangunan tempat ibadah (Vihara). Hal ini perlu ada upaya pencabutan undang-undang supaya memberikan rasa yang lebih adil, demokratis dan menghargai kemajemukan.

Upaya penutupan secara paksa sekelompok orang terhadap kehadiran dan keberadaan suatu tempat peribadatan pernah terjadi di wilayah Indonesia. Ini dimulai dengan alasan terganggunya kenyamanan, ketertiban serta keharmonisan hubungan antara umat beragama di lingkungan tersebut. Lambat laun ketidakharmonisan tersebut dapat memicu emosi masyarakat menjadi suatu gerakan massa yang dapat merugikan umat beragama. Berdirinya rumah ibadah yang tidak tepat pada tempatnya, misalnya berada di tengah-tengah pemukiman padat penduduk, sehingga menyebabkan setiap ada kegiatan peribadatan, penduduk setempat merasa terganggu ketenteramannya. Oleh karena itulah pemerintah mengeluarkan Peraturan Bersama 2 (dua) Menteri sebagai acuan mendirikan rumah ibadah yaitu Peraturan Bersama Menteri Agama dan Menteri Dalam Negeri (PBMA dan MDN) Nomor 8 Tahun 
2006 dan Nomor 9 Tahun 2006, selanjutnya disebut SKB 2 Menteri, yang membahas tentang pendirian rumah ibadah dan pedoman penyiaran agama. Pemerintah seharusnya mengusahakan untuk membuat aturanaturan penjelas yang lebih detail, mengenai 2 (dua) hal yang saling berkaitan, yaitu pembinaan kerukunan umat beragama melalui pembentukan Forum Kerukunan Umat Beragama (FKUB) dan prosedur pendirian rumah ibadah.

Kebutuhan rumah ibadah agama adalah menjadi hal yang sangat penting keberadaanya di Kota Tangerang. Rumah ibadah agama Buddha atau sering disebut Vihara/Cetya. Tingkat populasi umat Buddha yang terus berkembang diperlukan pendirian rumah ibadah sebagai tempat untuk belajar dan meningkatkan keyakinan terhadap Triratna. Dalam Undang-Undang Dasar 1945 Pasal 29 ayat (2) "Negara menjamin kemerdekaan tiap-tiap penduduk untuk memeluk agamanya masingmasing dan untuk beribadah menurut agama dan kepercayaan itu". Oleh karena itu memeluk agama atau kepercayaan dari agama atau kepercayaan yang ada di Indonesia adalah keharusan yang harus dijalankan setiap warga negara.

\section{B. METODE PENELITIAN}

Penelitian ini merupakan penelitian kualitatif dengan menggunakan pendekatan yuridis dan religius mengenai pendirian rumah ibadah agama Buddha di Kota Tangerang. Metode yang digunakan adalah metode penelitian kualitatif yang berkaitan dengan problematika secara yuridis dan religius mengenai pendirian rumah ibadah agama Buddha di Kota Tangerang. Adapun analisis data yang dilakukan menggunakan analisa kualitatif dengan model Miles and Huberman. Penelitian ini menjelaskan mengenai problematika yang terjadi dalam kehidupan masyarakat di Kota Tangerang, serta permasalahan yang terjadi dalam pendirian vihara, Proses pendirian Vihara yang mengalami berbagai kendala, cara mengatasi kendala tersebut serta permasalahan-permasalahan lain yang muncul baik permasalahan internal maupun eksternal. 


\section{PEMBAHASAN}

\section{Problematika Aspek Yuridis dan Religius Pendirian rumah Ibadah agama Buddha}

a. Aspek Yuridis

Tata cara pendirian rumah ibadah diatur dalam Peraturan Bersama Menteri Agama dan Menteri Dalam Negeri Nomor 8 dan Nomor 9 Tahun 2006 tentang Pedoman Pelaksanaan Tugas Kepala Daerah/Wakil Kepala Daerah dalam Pemeliharaan Kerukunan Umat Beragama, Pemberdayaan Forum Kerukunan Umat Beragama (FKUB), dan Pendirian Rumah Ibadah.

Pada Pasal 13 Peraturan Bersama Menag dan Mendagri No. 8/9 Tahun 2006, disebutkan bahwa pendirian rumah ibadah didasarkan pada keperluan nyata dan sungguh-sungguh berdasarkan jumlah penduduk bagi pelayanan umat beragama yang bersangkutan di wilayah kelurahan/desa. Pendirian rumah ibadah ini dilakukan dengan tetap menjaga kerukunan umat beragama, tidak mengganggu ketentraman dan ketertiban umum, serta mematuhi peraturan perundang-undangan. Apabila keperluan nyata bagi pelayanan umat beragama di wilayah kelurahan/desa tidak terpenuhi, maka pertimbangan komposisi jumlah penduduk digunakan batas wilayah Kecamatan atau Kkabupaten/kota Provinsi.

Pendirian rumah ibadah wajib memenuhi persyaratan administratif dan persyaratan teknis bangunan gedung. Demikian juga harus memenuhi persyaratan khusus, meliputi:

1. Daftar nama dan Kartu Tanda Penduduk pengguna rumah ibadah paling sedikit 90 orang yang disahkan pejabat setempat sesuai dengan tingkat batas wilayah;

2. Dukungan masyarakat setempat paling sedikit 60 orang yang disahkan oleh lurah/kepala desa;

3. Rekomendasi tertulis dari kantor departemen agama kabupaten/kota;

4. Rekomendasi tertulis FKUB Kabupaten/Kota.

Permohonan pendirian diajukan oleh panitia pembangunan rumah ibadat kepada Bupati/Walikota untuk memperoleh IMB rumah ibadah. Bupati/Walikota memberikan keputusan paling lambat 90 hari sejak permohonan pendirian rumah ibadat diajukan oelh panitia.Izin sementara pemanfaatan bangunan gedung bukan rumah ibadat sebagai rumah ibadat sementara harus mendapat surat keterangan pemberian izin sementara 
dari bupati/walikota. Penerbitan surat keterangan pemberian izin sementara dapat dilimpahkan kepada Camat. Sebelum surat izin diterbitkan, bupati/walikota/camat harus mempertimbangkan pendapat tertulis kepala Kantor Kemenag dan FKUB kabupaten/kota. Izin ini hanya berlaku selama 2 (dua) tahun. Adapun persyaratan untuk mendapatkan izin sementara ini, meliputi:

1. Izin tertulis pemilik bangunan;

2. Rekomendasi tertulis lurah/kepala desa;

3. Pelaporan tertulis kepada FKUB kabupaten/kota; dan

4. Pelaporan tertulis kepada kepala kantor kementerian agama kabupaten/kota.

Berkaitan dengan kepengurusan pendirian rumah ibadah agama Buddha di Kota Tangerang, sebelum surat diterbitkan bupati/walikota maka dipertimbangkan pada FKUB Kotamadya dan disetujui oleh Pembimas Banten.

\section{b. Aspek Religius}

Secara hakiki sebenarnya nilai ini merupakan nilai yang memiliki dasar kebenaran yang paling kuat dibandingkan dengan nilai-nilai sebelumnya. Nilai ini bersumber dari kebenaran tertinggi yang mencakup nilai sangat luas dan mengatur seluruh aspek dalam kehidupan manusia. Nilai ini terbagi berdasarkan jenis agama yang dianut oleh manusia, dan kebenaran nilai ini mutlak bagi pemeluk agamanya masing-masing.

Aspek religius dalam agama Buddha terdiri dari 3 aspek yakni aspek Keyakinan (Saddha), Perilaku (Sila) dan Bakti (Bhakti).

\section{1) Aspek Keyakinan (Saddha)}

Keyakinan adalah kepercayaan yang berdasarkan kebijaksanaan. Buddha telah mengajarkan suatu kebenaran mutlak yang merupakan kebenaran yang tidak diragukan. Agama Buddha dalam mendasari kepercayaanya bukan didasarkan kepada kepercayaan yang membabibuta atau tanpa dasar, setelah melalui penyelidikan awal orang dapat mengembangkan suatu penelitian dan mengujinya melalui pengalaman pribadi dan kepercayaan berakhir dengan pengukuhan yang rasional. Orang yang kuat dalam keyakinan tetapi lemah dalam kebijaksanaan akan memiliki keyakinan yang fanatik yang tanpa dasar. Orang yang kuat dalam kebijaksanaan dan lemah keyakinan akan mengetahui bahwa ia bersalah jika ia berbuat kejahatan, tetapi sulit untuk menyembuhkannya. Saddha mengandung tiga unsur : 

a. Keyakinan yang kuat akan suatu hal
b. Kegembiraan yang dalam akan sifat-sifat baik
c. Harapan untuk memperoleh sesuatu dikemudian hari

Keyakinan yang kuat bukan berarti hanya sebatas percaya seperti yang lazim dikenal oleh orang banyak. Keyakinan di sini menekankan aspek melihat, mengetahui dan memahami. Persoalan percaya akan timbul apabila tidak dapat melihat sesuatu dengan jelas. Melihat atau membuktikan (ehipassiko), akan membuat keyakinan memiliki kepastian, bukan percaya kepada sesuatu yang masih belum jelas benar.

Kegembiraan terhadap sifat-sifat yang baik ditemukan pada orang yang memiliki pengertian dan kebijaksanaan. Dengan keyakinan ini, semangat kesadaran, konsentrasi dan kebijaksanaan berkembang terus menerus. Keyakinan adalah kekayaan yang terbaik yang dimiliki oleh seseorang. Kekayaan yang dimaksud bukan hanya kekayaan harta benda, tetapi juga sukses dalam kehidupan sosial, hingga dilahirkan di alam surga, dan puncaknya mencapai Nibbana.

Ada empat pokok keyakinan yang paling utama, yaitu: keyakinan kepada Buddha, keyakinan kepada Jalan Mulia Berunsur Delapan, keyakinan kepada Nirwana, dan keyakinan kepada Ariya Sangha. Keyakinan kepada Buddha berarti memiliki keyakinan pada perenungan sempurna dari Tathagata (Tathagata-Saddha), keyakinan ini juga terkait pada keyakinan terhadap hukum karma atau perbuatan (Kamma-Saddha); keyakinan terhadap akibat dari karma (Vipaka-Saddha), keyakinan bahwa semua makhluk mempunyai karma masing-masing dan bertanggung jawab atas perbuatannya sendiri.

\section{2) Aspek Perilaku (Sila)}

Sila adalah etika atau moral yang dilakukan berdasarkan cetana atau kehendak. Etika berasal dari bahasa Yunani yaitu ethos yang artinya kebiasaan atau adat. Etika sering dijelaskan sebagai moral. Dalam pandangan Buddhis sila memiliki banyak arti antara lain: norma (kaidah), peraturan, perintah, sikap, keadaan, perilaku, sopan santun.

Sila pertama kali diajarkan Buddha kepada lima orang pertapa ketika menyampaikan khotbah pertama di Taman Rusa Isipatana. Dalam khotbah tersebut dijelaskan tentang jalan menuju lenyapnya dukkha yang dinamakan jalan tengah. Dalam jalan tengah Sila memiliki kelompok Ucapan benar, Perbuatan benar dan Mata Pencaharian benar. Sila merupakan dasar yang paling utama dalam pengamalan kehidupan 
beragama. Dengan memiliki agama merupakan langkah awal yang sangat penting untuk mencapai kehidupan yang luhur.

Manfaat melaksanakan sila adalah bebas dari penyesalan, bebas dari penyesalan menimbulkan kebahagiaan, kegembiraan dapat menimbulkan kegiuran (piti), kegiuran dapat menimbulkan ketenangan (passadi) ketenangan akan menimbulkan pemusatan pikiran (ekaggata), pemusatan akan menimbulkan pengetahuan mengenai kesunyataan (anulomanana), pengetahuan mengenai kesunyataan akan mendorong untuk mencari kebenaran (muncitukannyata nana), usaha untuk mencari kebebasan akan mendapatkan pengetahuan tentang kebebasan (nibbana nana), pengetahuan tentang kebebasan akan membawa orang kepada kebebasan (nibbana).

\section{3) Aspek Bhakti}

Bakti Buddhis adalah salah satu bagian praktik terpenting dalam agama Buddha. Buddha telah menunjukkan mengenai wujud bakti seperti membaca paritta dan mengulang Sutta. Sutta adalah kotbah Buddha yang berisi bagaimana berbuat kabajikan.

Nilai religius merupakan salah satu dari berbagai klasifikasi nilai di atas. Nilai religius bersumber dari agama dan mampu merasuk ke dalam jiwa. Nilai religius perlu ditanamkan dalam lembaga pendidikan untuk membentuk budaya religius yang mantab dan kuat di lembaga pendidikan tersebut. Di samping itu, penanaman nilai religius ini penting dalam rangka untuk memantabkan etos kerja dan etos ilmiah seluruh civitas akademika yang ada di lembaga pendidikan tersebut. Selain itu, juga supaya tertanam dalam diri tenaga kependidikan bahwa melakukan kegiatan pendidikan dan pembelajaran pada peserta didik bukan sematamata bekerja untuk mencari uang, tetapi merupakan bagian dari ibadah.

Problematika dalam proses pendirian Vihara beragam baik dari internal yakni umat Buddha dan eksternal yaitu dari umat agama lain dan masyarakat sekitar komplek Vihara. Problema yang muncul dapat diatasi dengan menjalin komunikasi antar pemeluk agama dan pemuka masyarakat. Ini dilakukan secara terus menerus sehingga masalah yang besar pelan-pelan dapat diatasi. Berkaitan dengan hal tersebut maka perlu dilakukan penyelidikan atau penelitian yang dapat memberikan jawaban tentang problematika aspek yuridis dan relegius dalam pendirian rumah ibadah agama Buddha. 


\section{Syarat-syarat Pendirian Rumah Ibadah}

Sesuai dengan Undang-undang dan Peraturan yang berlaku bagi pihak yang bermaksud mendirikan rumah ibadah terlebih dahulu diharuskan melengkapi dan memenuhi berbagai persyaratan yakni sebagai berikut:

a. Ada calon pengguna rumah ibadah minimal 90 orang.

b. Mendapatkan persetujuan wargasetempat minimal 60 penduduk

Setelah dilakukan pemeriksaan terhadap data pendukung sesuai dengan persyaratan yang ditentukan oleh peraturan dan Undangundangyang berlaku diketahui beberapa fakta sebagai berikut:

a. Kurang lebih ada 200 kepala keluarga daftar nama calon pengguna rumah ibadah yang akan didirikan.

b. Daftar nama calon pengguna rumah ibadah tersebut terdapat beberapa nama yang alamat tinggalnya dalam catatan KTP tersebut dari beberapa kecamatan dan berbagai kabupaten dan kota.

Pendirian rumah ibadah harus memenuhi persyaratan administrasi seperti surat keterangan ke pemilik tanah persyaratan teknis bangunan gedung (seperti persyaratan tata bangunan gedung). Selain memenuhi persyaratan sebagaimana dimaksud di atas, pendirian rumah ibadah harus memenuhi persyaratan khusus,yaitu:

a. Daftar nama dan Kartu Tanda Penduduk(KTP) pengguna rumah ibadah paling sedikit 90 orang yang disahkan oleh pejabat setempat sesuai dengan tingkat batas wilayah.

b. Dukungan masyarakat setempat paling sedikit 60 orang yang disahkan oleh lurah/kepala desa.

c. Rekomendasi tertulis kepada kantor Departemen Agama kabupaten/kota.

d. Rekomendasi tertulis Forum Kerukunan Umat Beragama (FKUB) kabupaten/kota yang merupakan hasil musyawarah dan mufakat dalam rapat Forum Kerukunan Umat Beragama, dituangkan dalam bentuk tertulis. 


\section{PenyebabTerjadinya Konflik Pendirian Rumah Ibadah di Kota Tangerang}

Konflik yang terjadi dalam pendirian rumah ibadah di Cipondoh Kota Tangerang adalah konflik internal dan konflik eksternal. Konflik internal adalah berkaitan dengan pengumpulan KTP, pendanaan, sedangkan masalah eksternal melibatkan pihak-pihak terkait seperti Rukun Tetangga(RT) dan Rukun Warga (RW) dan protes warga yang pada awalnya vihara didirikan karena berada di rumah penduduk.

Keresahan masyarakat ini disebabkan kurang komunikasi antar warga masyarakat. Dalam perkembangannya masalah ini dapat diatasi dengan komunikasi intensif oleh pengurus Vihara dengan pengurus desa dan aparat keamanan. Mengenai pendirian rumah ibadah yangkurang memenuhi syarat pihak pengurus Vihara telah melakukan langkahlangkah admnistrasi dan hukum serta bekerjasama dengan Forum Kerukunan Umat Beragama (FKUB) wilayah Banten. Selain itu pengurus vihara telah berkoordinasi dengan Kanwil wilayah Banten dalam proses pendirian vihara.

\section{Upaya Mengatasi Problematika dalam proses pendirian vihara.}

Problema yang muncul adalah secara eksternal adalah adanya bentuk protes dari beberapa orang di masyarakat. Problema secara religius adalah dari umat Buddha ketidakcocokan pendapat dalam proses pendirian Vihara. Solusi yang dilakukan adalah dengan komunikasi dengan masyarakat dan aparat setempat sehingga masalah dapat diatasi.

Hasil penelitian penulis menunjukkan bahwa ada problema yang muncul baik dari dalam (internal) maupun dari luar (eksternal). Problematika dari dalam dapat diatasi dengan musyawarah dengan pengurus Vihara sedangkan masalah eksternal yakni dimasyarakat adalah dengan menjalin komunikasi secara sistematis sehingga tercipta saling hormat menghormati dengan masyarakat setempat.

Dari apa yang diuji oleh Forum Kerukunan Umat Beragama (FKUB) mengenai masalah ini,ada juga permasalahan yang berasal dari lokasi yang akan digunakan untukpendirian rumah ibadah tersebut adalah tanah fasilitas umum (fasum)

Dalam aturan pemerintah daerah bahwa seyogyanya lahan fasilitas umum untuk keperluan tempat ibadah keperluan tempat ibadah diserahkan pada pemerintah daerah melalui tim verifikasi fasilitas sosial/fasilitas umum, yang oleh Pemerintah Daerah akan dijadikan sesuai dengan pengesahan site plan bahwasannya lokasi tersebut akan dijadikan sebagai pertokoan 


\section{PENUTUP}

Problematika yang terjadi dalam proses pendirian rumah ibadah adalah sangat beragam. Problem internal terjadi dikarenakan ketidaksamaan visi dan tujuan dibangunnya rumah ibadah. Kurang sepaham visi dan tujuan tersebut terjadi masalah di dalamnya. Problem yang muncul adalah perbedaan pendapat dan kepentingan. Problem tersebut dapat diatasi dengan cara musyawarah antar pengurus vihara dan umat Buddha. Problem eksternal yakni dalam hubungannya dengan tempat didirikan tempat ibadah tersebut dan masalah administrasi yang mengatur di dalamnya. Masalah tersebut dapat diatasi dengan melakukan komunikasi dengan tokoh masyarakat setempat dalam bentuk musyawarah serta bekerjasama dengan pihak-pihak yang berkepentingan. Upaya yang untuk mengatasi setiap permasalahan yang terjadi pengurus Vihara mempunyai inisiatif melakukan dialog dengan membuka kesempatan mendengar penjelasan masing-masing pihak yang berkonflik. Setelah itu konflik dapat diidentifikasi, tujuan-tujuan yang tidak sama dan saling bertentangan dapat diatasi dengan baik.

Hal-hal yang perlu diperbaiki bagi pengurus vihara dalam aspek religius adalah dengan peningkatan pelaksanakan ritual keagamaan. Dalam aspek hukum adalah dengan lebih intensif melakukan upaya mengurus secara administratif sehingga proses pendirian vihara dapat terlaksana secara resmi. Bagi Ditjen Bimas Buddha agar menyusun kebijakan-kebijakan yang mendukung dalam terciptanya kerukunan antar umat beragama. Bagi umat Buddha perlu memberikan saran dan kritik yang membangun kepada pengurus vihara jika dalam hal pelayanan umat Buddha yang kurang maksimal.

\section{DAFTAR PUSTAKA}

Agus Prasetya, Farid. 2014. Problematika Pendirian Rumah Ibadah dalam Perspektif Ketatanegaraan (studi kasus atas pembangunan komplek padmasambhava Stupa di Dusun Beijen Wanurejo, Kec. Borobudur, Magelang), Universitas Islam Negeri Sunan Kalijaga, Yogyakarta.

Ali Ahmad, Haidlor. 2012. Hubungan Umat Beragama: Studi Kasus Penutupan/Perselisihan Rumah Ibadah, Puslitbang Kehidupan Keagamaan Badan Litbang dan Diklat Kementerian Agama RI. Jakarta. 
Asry, Yusuf. 2012. Pendirian Rumah Ibadah Di Indonesia (Kementrian Agama

RI Badan Litbang dan Diklat Puslitbang Kehidupan Keagamaan).

Jakarta.

Danim, Sudarwan. 2002. Menjadi Peneliti Kualitatif. Bandung : Pustaka Setia. Hakim, Bashori. A. 2004. Fungsi Sosial Rumah Ibadah dari Berbagai Agama, Proyek Peningkatan Pengkajian Kerukunan Umat Beragama. Puslitbang Kehidupan Beragama, Badan Litbang Agama dan Diklat Keagamaan, Departemen Agama RI. Jakarta.

Kamus Besar Bahasa Indonesia, 2008. Balai Pustaka. Jakarta.

Nasution, 1992. Metode Research. Yogyakarta: Rake Sarasin.

Santoso, Urip. 2005. Hukum Agraria dan Hak-hak Tanah. Kencana.

Soerojo, Irawan. 2003. Kepastian Hukum Hak atas Tanah di Indonesia.

Sugiyono. 2007. Metode Penelitian Kuantitatif Kualitatif dan $R \mathcal{E} D$. Bandung: Alfabeta.

Sumaryo, dkk. 2006. Efektifitas Sosialisasi Bersama Menteri Nomor 9 dan 8 Tahun 2006 Tentang Pedoman Pelaksanaan Tugas Kepala Daerah/Wakil Kepala Daerah dalam Pemeliharaan Kerukunan Umat Beragama, Pemberdayaan Forum Kerukunan Umat Beragama dan Pendirian Rumah Ibadah. Puslitbang Kehidupan Keagamaan, Badan Litbang dan Diklat Departemen Agama RI. Jakarta.

Sunggono. 2005. Bambang. Penelitian Hukum. PT. Raja Grafindo Persada. Jakarta.

\section{PeraturanPerundang-undangan:}

Peraturan Bersama Menteri Agama Nomor : 9 Tahun 2006 dan Menteri Dalam Negeri Nomor :8 Tahun 2006 Tentang Pedoman Pelaksanaan Tugas Kepala Daerah/Wakil Kepala Daerah Dalam Pemeliharaan Kerukunan Umat Beragama, Pemberdayaan Forum Kerukunan Umat Beragama, Dan Pendirian Rumah Ibadat

Keputusan Bersama Menteri Agama dan Menteri Dalam Negeri Nomor. 1

Tahun 1979 Tentang Tatacara Pelaksanaan Penyiaran Agama Dan

Bantuan Luar Negeri Kepada Lembaga Keagamaan Di Indonesia;

Keputusan Bersama Menteri Agama Dan Menteri Dalam Negeri No. 01/BER/Mdn-Mag/1969 Tentang Pelaksanaan Tugas Aparatur

Pemerintahan Dalam Menjamin Ketertiban Dan Kelancaran Pelaksanaan Pengembangan Dan Ibadat Agama Oleh PemelukPemeluknya 112 Keputusan Menteri Agama Nomor. 77 tentang Bantuan Asing Bagi Lembaga Keagamaan di Indonesia. 